\title{
Exposure as Collected Name of Treatment
}

National Cancer Institute

\section{Source}

National Cancer Institute. Exposure as Collected Name of Treatment. NCI Thesaurus. Code $C 117473$.

The literal identifier of the exposure as collected. 